\title{
The Evolving Role of the European Commission in the Enforcement of Community Law: From Negotiating Compliance to Prosecuting Member States?
}

\section{Anne Bonnie}

\section{Introduction}

For a number of years, the European Community has been faced with Member States increasingly failing to comply with Community law. The issues raised by the 'non-compliance phenomenon'1 have been addressed in a variety of ways in the Community legal order. Articles 226/228 of the European Community Treaty ${ }^{2}$ have for primary purpose to secure compliance by Member States through the authority of the rulings of the European Court of Justice, and since the Maastricht Treaty, through the threat or the imposition of pecuniary sanctions. The European Commission itself is contributing to the compliance effort by making a much more systematic use of infringement procedures. The pressure exercised upon Member States to discharge their Community obligations is mounting. The necessary corollary of this is an increasing focus on enforcement actions at Community level, evidenced in the Commission's White Paper on European Governance $^{3}$ which refers to the aim of a more effective enforcement of Community law as necessary to strengthen the credibility of the Union and its institutions. ${ }^{4}$ The White Paper identifies five principles of good governance: openness, participation, accountability, coherence and effectiveness as key for a successful reform of governance in Europe. ${ }^{5}$ Of those principles, that of effectiveness is paramount in terms of enforcement, as it affects the respective functions of the Commission in overseeing the application and enforcement of European policies and of the Member States in developing and implementing them.

While there is abundant literature on the issue of European governance in general and on its implications in terms of policy making in particular, ${ }^{6}$ little attention has so far been paid to the impact of new governance on the role of the Commission in the monitoring and enforcement of Community law. The White Paper's general approach to enforcement hinges on the re-assessment and improvement of the traditional, 'hard law' infringement procedures of Articles 226 and 228 ECT. This raises the issue of the suitability of such an approach, as new governance relies upon the introduction of new, softer policy making instruments, ${ }^{7}$ where the specific nature of the legal obligation is notoriously difficult to establish... and therefore to enforce under current Treaty provisions. The analysis which follows must thus be conducted with the knowledge that important elements of future Community policies may potentially remain outside of the reach of the Commission's enforcement policy as shaped by the White Paper.

After a brief overview of the Commission's traditional role in infringement procedures, this article examines the impact of the White Paper on the role of the European Commission in situations of both pre-litigation and post-litigation non-compliance.

Firstly, it is demonstrated that the implementation of the White Paper has resulted in the limited introduction of selected elements of new governance, which all converge towards a substantial reinforcement of the role of the Commission as the negotiator of the Member States' compli- 
ance. Secondly, the analysis shows that the role of the Commission is increasingly inscribed in a litigation management and litigation avoidance framework. Thirdly, while it is acknowledged that the strengthening of the negotiator's role of the Commission within the new framework goes someway towards enhancing the overall effectiveness of infringement actions in cases of pre-litigation non-compliance, its contribution to improving the effectiveness of infringement actions in instances of post-litigation non-compliance is questioned. Finally, the suggestion is put forward that in the latter circumstances, the effectiveness of the enforcement of Community law would perhaps be better served by the Commission acting more as a prosecutor on behalf of the Community than as a negotiator.

\section{The Commission's traditional role in infringement actions}

The Commission is commonly described as the 'guardian of the European treaties', ${ }^{8}$ a function embodied in Article 211 E.C. ${ }^{9}$ which stipulates that 'in order to ensure the proper functioning and development of the common market, the Commission shall ensure that the provisions of this Treaty and the measures of the institutions pursuant thereto are applied.' The Commission's role has been further defined by the European Court of Justice in the following terms: '[U]nder Articles 155 and 169 of the Treaty, its function is to ensure that the provisions of the Treaty are applied by the Member States and to note the existence of any failure to fulfil the obligations deriving therefrom, with a view to bringing it to an end'. ${ }^{10}$ In the area of enforcement, the Commission exercises its powers in two distinct sets of circumstances, referred to as pre- and post litigation non-compliance.

\section{Pre-litigation non-compliance}

Pre-litigation non-compliance may be defined as situations in which the alleged breach of EC law has taken place but its existence remains to be judicially established. From this perspective, the occurrence of an infringement is suspected and its legal reality has yet to be clearly declared by the European Court of Justice. In the EC Treaty, Articles 226 and 228(1) are precisely aimed at these types of circumstances. ${ }^{11}$

The enforcement procedure under Article 226 ECT aims at clarifying the legal situation where the Commission's attention is drawn to a suspected infringement. The clarification process is based on an exchange of information between the Commission and the Member State concerned. The procedure is governed by a spirit of co-operation leading to an amicable cessation of the breach of EC law in the great majority of cases. The resolution of the dispute may simply result from the fact that the national authorities of the Member State concerned have satisfied the Commission that there is no infringement of Community law by providing additional information. Alternatively, if an infringement was indeed uncovered, the Member State has taken into account the Commission's opinion and brought the violation to an end.

In summary, Article 226 ECT advocates voluntary compliance through conciliation. The statistics covering 30 years of application of Article 226 ECT, published by the Commission in the run up to the White Paper on Governance, ${ }^{12}$ confirm the efficacy of the negotiation-based approach. The report covers the 1972-2001 period and establishes that, on average, for one hundred letters of formal notice sent, 36 reasoned opinions are issued and 10 referrals to the ECJ made. Overall, the Commission started 16,714 Article 226 actions over the reference period, of which 14,452 $(86.46 \%)$ where terminated without need to be referred to the Court of Justice. ${ }^{13}$

\section{Post-litigation non-compliance}

The concept of post-litigation non-compliance refers to situations in which 'the non-compliance occurs after the judicial determination that certain conduct or absence of conduct does indeed constitute non-compliance with agreed rules'. ${ }^{14} \mathrm{~A}$ more in-depth examination of that definition reveals that post-litigation non-compliance comprises three main elements. Firstly a breach of Community obligation(s) by a Member State, secondly the confirmation of the existence of the specific breach by a court of law, i.e. in our particular case the European Court of Justice, and finally a subsequent infringement consisting of the failure of the Member State to comply with 
the judgment of the Court. Within the EC Treaty, Article 228(2) ECT is specifically designed to address the issue of post-litigation non-compliance. ${ }^{15}$ The innovation brought in by this provision resides in the fact that an enforcement procedure whose scope covers infringement of any EC Treaty provision now potentially leads to the imposition of monetary sanctions upon offending Member States. ${ }^{16}$ In the immediate period following the entry into force of Article 228(2) ECT, the Commission's use of the new infringement procedure can at best be described as timid. ${ }^{17}$ This may partly be explained by the fact that a number of clarifications were required, particularly regarding the method to be used in order to calculate the pecuniary sanctions attached to Article 228(2)..$^{18}$ The number of infringement actions for non compliance with rulings of the ECJ has since steadily increased. ${ }^{19}$

The Commission plays a pivotal role during both Article 226 and Article 228(2) ECT procedures, collating information regarding the detection of infringements from various sources such as complaints lodged by individuals, petitions presented by the European Parliament or 'own initiative' investigations. ${ }^{20}$ It also provides Member States with advice on how to bring to an end a detected infringement. As far as the unfolding of the procedure is concerned, the Commission benefits from a wide discretion ${ }^{21}$ in deciding whether and when to take the successive steps eventually leading to the closure or the referral of the case. ${ }^{22}$ In using its discretion, the Commission exercises the power to decide upon the most appropriate means of ensuring the application of Community law. ${ }^{23}$ The only limitations brought by the European Court of Justice to that discretion are based on the protection of the Member States' defence rights. ${ }^{24}$

The Commission's autonomy in that area is supported by a variety of arguments ranging from the legal to the political and material. Legally, the wording of the Treaty does confer a degree of discretion to the Commission ${ }^{25}$ and in its relevant case-law the European Court of Justice has consistently interpreted these provisions in a sense favourable to the Commission. ${ }^{26}$ Politically, the Commission decides upon the areas to be targeted in priority through infringement actions, such as the single market for example. ${ }^{27}$ Furthermore, purely material considerations may play an important role, as the Commission's available resources do not stretch to infinity. Finally, the need for and advantages of, flexibility in the dealings with the Member States are equally important factors. ${ }^{28}$ As a consequence, the Commission enjoys a strong bargaining power in its relationships with the Member States.

\section{The White Paper and pre-litigation non-compliance: expanding and strengthening the Commission's role as negotiator}

Turning now to the implementation of the White Paper and its impact, the analysis focuses first on the identification of elements of new governance affecting the Commission's role as guardian of the treaties, before assessing their impact.

\section{Identifying the factors affecting the Commission's role: cooperation and selectivity}

The approach to the monitoring and control of the application of Community law adopted in the White Paper contributes to the aim of improved effectiveness by giving a new prominence to the administrative practices of cooperation and selectivity, which had so far operated in the shadowy background of the Commission's enforcement policy. Both these practices significantly contribute to increase the Commission's role as negotiator.

\section{Cooperation}

The White Paper and subsequent documents ${ }^{29}$ introduce a further dimension, cooperation, to the traditional bipolar allocation of enforcement responsibilities. They acknowledge that effectiveness cannot be achieved if both Member States and Commission do not work jointly towards the same end. Cooperation is presented as a means to reduce the need for the monitoring and the control of the application of Community rules. The spirit of democratic governance means that cooperation between the Commission and the Member States should be associated with monitoring so that effectiveness can be achieved without constraints, with only a minimum of controls but in a climate of mutual knowledge and trust, that can only be built as a result of a proactive preven- 
tive approach - it is always preferable to cooperate more closely in preventing infringements so as to avoid conflict situations. ${ }^{30}$ The idea that cooperation should form an intrinsic part of the Commission's enforcement policy is hardly innovative, as it reflects the origins of an enforcement procedure described elsewhere as an 'elite model of regulatory bargaining' characterised by an informal, discretionary, co-operative and closed process. ${ }^{31}$ In practice, informal cooperation between the Commission and the Member States has featured regularly during the administrative stage of infringement proceedings. However, in bringing it to the fore, the White Paper transforms cooperation from an administrative practice of cooperation into an 'institutionalised' policy instrument. The juridification of cooperation opens up a new field for the Commission to act in a negotiator's capacity in 'upstream' situations to prevent infractions to Community law and confers a new status to the cooperative practice already existing in 'downstream' situations to facilitate the investigation of suspected infringements.

Upstream negotiation and the emergence of compliance partnerships

The new upstream cooperative approach to enforcement is aimed at avoiding litigation. It involves a re-evaluation of the contribution made by the Member States and the Commission to the effectiveness of Community law as well as the exercise of their respective responsibilities at an adequate level in order to prevent infringements from arising in the first place. ${ }^{32}$ This type of cooperation may be described as a compliance partnership in which an exchange of information regarding the correct implementation of Community law and a constant dialogue between Commission and Member States are paramount. Such dialogue already exists during the prelitigation phase of Article 226 ECT where it enables a Member State voluntarily to come into line with Community law. Allowing the dialogue to take place at a much earlier stage, well before any initiation of infringement proceedings, is beneficial at several levels. First, it may prevent breaches of Community law, thus contributing to the swift and correct application of Community law and enhancing its effectiveness. Second, it may render lengthy and costly litigation unnecessary, in turn saving both resources and court time.

Concretely, prevention is to be achieved through a variety of practical cooperation instruments such as: the issuing by the Commission of interpretative communications on specific matters of Community law, the sharing of good practices at national and Community level, the creation within the Member States of single coordination points responsible for the application of Community rules, the recourse to 'package meetings' at a much earlier stage, and the offer of technical assistance in the event of transposal problems. ${ }^{33}$ The first practical outcomes of the new upstream cooperation process have started to emerge, in the form of early package meetings to discuss transposition difficulties with national administrations, information seminars on the correct implementation of complex directives, and regular contacts between the permanent representations of the Member States and the Secretariat-General of the Commission. ${ }^{34}$

However, upstream, pre-infringement cooperation and negotiation are only one aspect of the Commission's role in situations of pre-litigation non-compliance. It runs in parallel with the more familiar functions of control and enforcement triggered by the initiation of proceedings in accordance with Article 226 ECT.

\section{Downstream negotiation and enforced co-operation}

Downstream negotiation occurs once an infringement procedure is started by the Commission. In contrast to the upstream-type cooperation, downstream negotiation has the primary objective to encourage the Member State involved to comply voluntarily with Community law as quickly as possible. The negotiation therefore occurs in a more adversarial context in which the Commission acts as enforcer and the Member States are being formally investigated. This change of both context and purpose has an impact on how cooperation and negotiation are approached. In the White Paper, the Commission made it clear what the Member States' responsibilities are, ${ }^{35}$ and this involves an obligation of cooperation based on the loyalty clause of Article 10 ECT. ${ }^{36}$ During the investigation of infringements, considerable delays are often caused by difficulties in gathering all the evidence relating to an infringement owing to a lack of cooperation insufficient 
cooperation on the part of national authorities at all levels. ${ }^{37}$ Article 10 provides a legal basis for the enforcement of the obligation of cooperation allowing the Commission to start infringement proceedings for the failure to comply with that duty. ${ }^{38}$ However, this method is not without some drawbacks. Though Article 10 is itself enforceable, a separate Article 226 ECT action on these grounds would only add a procedural layer, generating more work for the Commission. Even in the event that the procedure results in a finding that the Member State has failed to cooperate, it would not necessarily be conducive of compliance where the first infringement is concerned. This is why the Commission commonly uses Article 10 ECT as a back up legal basis in addition to the original grounds of infringement. ${ }^{39}$

The stricter application of Article 10 nevertheless distinguishes the approach to cooperation as applied in downstream situations, where it is possible to speak, somewhat paradoxically, of enforced cooperation. The general spirit of dialogue and willingness that permeates the initial stages of infringement proceedings and the concept of enforced cooperation may at first appear difficult to reconcile. The information provided by the Commission's statements on that particular issue denotes a gradual method, based on the postulate that Member Sates should be disposed to cooperate and leading to the imposition of an obligation of cooperation when necessary. This inherent element of flexibility leaves considerable scope for the Commission to exercise discretion and negotiate with the Member States concerned. ${ }^{40}$

\section{Selectivity}

In reflecting the traditional bi-polarisation of the Member States' and Commission's respective roles in the enforcement of Community rules, the White Paper confirms the Commission's longestablished enforcement method of focusing on the control of the application of Community law by the Member State. ${ }^{41}$ This, combined with the increase of the Commission's workload and the need for improved effectiveness, leads to a re-evaluation of the handling of infringement actions by the Commission and the prominent role to be played by a policy of selective enforcement. Selective enforcement has been described as a basic element of a good enforcement policy ${ }^{42}$ and has operated informally for some time within the Commission in the embryonic form of 'priorities in the processing of complaints'. ${ }^{43}$

Selectivity is concerned with improving the management of infringement procedures by establishing orientations to be followed in order to achieve a strategic use of the infringement procedure of Article $226 .{ }^{44}$ In that respect, selectivity is clearly linked to governance as it contributes to the increase of the Commission's effectiveness when exercising its function of control of the application of Community law.

The general philosophy of selectivity is based upon the acknowledgement that there is a need for greater flexibility in the treatment of alleged infringements. As the Commission's monitoring and control activities increase, they must be organised into priorities. This method is the result of the rationalisation of two factors: the availability of Commission's resources and the necessity to plan in advance the tasks to be completed.

Selectivity is not a reduction of the Commission's own competences as guardian of the treaties, nor is it meant to lead to alleged infringements being declared inadmissible or proceedings being terminated. ${ }^{45}$

Selectivity is thus presented as a managerial instrument designed to rationalise and streamline the processing of alleged infringements, and as a key factor in the effective use of available enforcement instruments. The Commission followed on the White Paper and produced a series of criteria to identify priority cases, reflecting the seriousness of the potential or known failure to comply with Community law. ${ }^{46}$ The following types of infringements are ranked as serious: infringements that undermine the foundations of the rule of law, infringements that undermine the smooth functioning of the Community legal system, ${ }^{47}$ and infringements consisting in the failure to transpose or the incorrect transposal of directives. ${ }^{48}$

In practice, where an infringement meets the priority criteria, proceedings under Article 226 ECT will be started immediately, unless the Commission believes that the situation can be remedied more rapidly by some other means. As far as lower priority cases are concerned, they will be primarily handled on the basis of complementary mechanisms without excluding the possibility of bringing infringement proceedings. Those complementary means of enforcement are identified as follows: ${ }^{49}$ overall negotiations with Member States in cases of repetitive violations of Commu- 
nity rules in a given sector; recourse to the SOLVIT network where issues regarding the internal market are involved; package meetings aimed at finding solutions outside legal proceedings; contacts with independent and specialised national authorities facilitating the achievement of the Commission's task as guardian of the treaties. Those alternatives to infringement actions have been used informally by the Commission in the past. ${ }^{50}$ However, the introduction of the selectivity principle marks their recognition as enforcement mechanisms and their integration as part of the Commission's management strategy of alleged infringements. A characteristic common to all complementary enforcement mechanisms is the substantial element of negotiation involved, and their development is likely to widen the Commission's field of intervention as a negotiator of the Member States compliance at the pre-litigation stage.

In a pattern already observed with the juridification of cooperation, the White Paper adds a further dimension to what was previously the informal administrative practice of selective enforcement, turning it into a key instrument of the Commission's enforcement policy. The emergence of a set of criteria for the exercise of selective enforcement is a welcome contribution towards transparency in the treatment of infringements. However, it must immediately be tempered by the lack of precision of some of those criteria. Indeed, which infringement does not, at some level, undermine the smooth functioning of the Community legal system? Furthermore, it is likely that the operation of the selectivity policy will prove difficult to evaluate, as the Commission's annual reports on monitoring the application of Community law do not give any information as to which infringements are dealt with through complementary enforcement mechanisms or directly through Article 226 ECT due to their seriousness.

To conclude on this point, the impact of the two key concepts of cooperation and selectivity on the Commission's role as negotiator of the Member States' compliance will now be evaluated. The emerging picture is a bi-dimensional one, showing both a widening of the scope for negotiations between the Commission and the Member States during the pre-litigation stage of infringement actions, and a strengthening of the Commission's own position during those negotiations. The re-enforcement of the Commission's role may be in part attributed to the juridification of existing non-legal practices, a paradoxical move given that one of the key features of the White Paper is a general trend towards 'soft law' options.

Assessing the impact of the White Paper: the litigation avoidance and litigation management framework

On the surface, cooperation and selectivity may appear to operate in separate spheres. Cooperation is mainly associated with the prevention of infringements, whereas selectivity is primarily perceived as a management tool in the processing of alleged infringements. However, the analysis of their combined effects reveals that the Commission's role as negotiator of the Member States' compliance is not limited to preventing or processing infringements actions. It is increasingly inscribed in the wider context of litigation avoidance and litigation management.

\section{Litigation avoidance}

It has been established that, in facilitating the prevention of infringements, the compliance partnerships established between the Commission and the Member States may remove the necessity of litigation altogether. Upstream cooperation is in that sense a powerful tool where the effectiveness of Community law is concerned. Similarly, in establishing criteria to distinguish between high and low priority infringements, selectivity allows recourse to complementary means of enforcement as a first resort where low priority infringements are concerned. In addition, by offering alternatives to the Article 226 procedure, complementary means of enforcement also contribute to the objective of litigation avoidance. The combined application of the cooperation and selectivity principles highlights the reinforcement of the Commission's role as a negotiator of the Member States' compliance in pre-litigation situations. The Commission occupies a centre stage position as a key participant in the compliance dialogue, either by working pro-actively to prevent infringements from arising or by providing a forum for bringing infringements to an end outside the formal Article 226 procedure.

Finally, it is to be noted that the creation of multiple opportunities for negotiation during the litigation avoidance stage has an impact on the Commission's position when litigation appears 
as the only available option. In such instance, the Commission's role as a negotiator is inscribed within the framework of effective litigation management.

\section{Litigation management}

Litigation is unavoidable in two sets of circumstances. Firstly in low priority cases, when complementary means of enforcements have failed to bring an infringement to an end. In such instances, an Article $226 \mathrm{ECT}$ procedure will be triggered as a last resort, and the negotiations between Commission and Member States are based on the concept of downstream, enforced cooperation. Secondly, litigation is accepted as the most effective way to deal with high priority cases, infringements that have a high negative impact on the effectiveness Community law. An example may be found in the recent evolution of the treatment of breaches relating to directives. The White Paper on Governance expressly identified the enforcement of directives as an area the Commission should focus upon, because ensuring the effectiveness and quality of transposition of directives is the most effective way of avoiding individual problems arising at a later stage. ${ }^{51}$ Following the White Paper on Governance, the Commission now systematically targets infringements relating either to the failure to notify the national implementation measures of directives, or to the non-conformity of domestic transposition measures with the Community directive. In 2003, the number of proceedings for failure to notify increased considerably compared to the figures for the year 2002, from 607 to 1166 cases, an augmentation of $92.1 \% .52$ By December 2003, Member States had on average notified $98 \%$ of national implementing measures necessary for the implementation of directives in all sectors. ${ }^{53}$ The figures for the number of procedures based on the incorrect transposition of directives remained stable. ${ }^{54}$ The improved management system of directives reflects well both the notion of enforced cooperation and selectivity. The obligation imposed upon Member States to notify domestic implementation measures is a clear example of enforced cooperation. The notification process was originally read as part of the Member States general obligation of cooperation under Article $10 \mathrm{ECT}$, and has now evolved into a specific obligation enshrined in each directive. It is routinely targeted as a source of infringement of Community law. The systematic nature of infringement proceedings in such cases ${ }^{55}$ is a straight forward application of the selectivity principle, reflecting the seriousness attached to the non-transposition or incorrect transposition of directives, which can in reality deprive large segments of the public of access to Community law and are actually a common source of infringements. ${ }^{56}$

To conclude on the issue of the role of the Commission in situations of pre-litigation non-compliance following the White Paper on European Governance, the analysis indicates a global reinforcement of its position as a negotiator. The introduction of a principle of upstream cooperation serves the crucial objective of developing compliance partnerships within which the Commission and the Member States operate as equal partners working jointly towards the common aims of infringement prevention and the effective application of Community law. The initiation of infringement proceedings however marks a shift from a fairly balanced partnership to a potentially unequal relationship through the threat, and at times the reality, of enforced cooperation on the basis of Article 10 ECT. In both cases, the Commission's position as a negotiator is considerably strengthened. The introduction and implementation of the selectivity principle has had a similar impact on the Commission's negotiator's role. It has widened the scope for negotiations when dealing with low priority cases, and reinforced the Commission's bargaining position in high priority cases. The analysis also shows that, when considering the Commission's function in the wider context of litigation avoidance and effective litigation management, an identical picture emerges of a global reinforcement of its role as negotiator.

\section{Post-litigation non-compliance: The European Commission as a prosecutor?}

Occurrences of post-litigation non-compliance are to be taken particularly seriously because they involve a double violation of Community law, comprising the 'original' infringement of EC law followed by the failure of the Member State to take all necessary measures to rectify the original infringement, in itself constitutive of a second violation. Furthermore, persistent infringements of key EC law principles or legal rules often have direct negative effects on the categories of people, 
businesses or objectives the EC legislation aims to protect or promote. A good example may be found in a recent case in which the ECJ actually imposed a hefty financial penalty on a Member State..$^{57}$ This case concerned the failure of French authorities to carry out controls ensuring compliance with Community measures for fishery conservation, an infringement which lasted for a period of over 21 years and had serious adverse consequences on the renewal of fish stocks. In the initial case, decided under the then Articlel69 ECT (now 226), the ECJ found that France had breached obligations regarding the control of the minimum mesh size for nets and the prohibition of the sale of undersize fish, and had failed to take action in respect to infringements of Community fishing regulations. ${ }^{58}$ The French authorities subsequently failed to take the measures necessary to comply with the ruling of the ECJ. This lead the Commission to start infringement proceedings under Article 171 (2) (now 228(2) EC), in August 2002.59 Upon referral of the case, the Court found France to be in breach of Article 228(2) for having failed to comply with its earlier judgment. It inflicted a periodic penalty payment of $57,761,250$ for each period of six months at the end of which the 1991 judgment has still not been fully implemented, starting from the day of the second ruling. ${ }^{60}$ In addition, the ECJ also ordered France to pay a lump sum of Euro 20,000,000, based on the assessment of the effects on public and private interests of the failure of the Member State concerned to comply with its obligations, in particular where the breach has persisted for a long period since the judgment which initially established it. ${ }^{61}$ It is the first time that the Court of Justice imposes both a periodic penalty payment and the payment of a lump sum under Article 228(2) ECT. ${ }^{62}$

This case displays the typical features of instances of post-litigation non-compliance: a persistent reluctance on the part of a Member State to come into line with Community law, the key part played by the Commission both in ensuring that rulings of the ECJ are complied with and in suggesting the imposition of financial sanctions, long and protracted litigation at Community level, and last but not least the significant effects of the non-compliance on the Community legal order and individual citizens. The evolution of the Commission's role during the procedure must therefore be examined in the light of both those specific features and the impact of the White Paper on Governance.

\section{Applying the White Paper's approach to situations of post-litigation non-compliance?}

Interestingly, the White Paper on Governance does not expressly refer to instances of post-litigation non-compliance. This omission is in itself remarkable given that, at the time, the number of ECJ judgments not yet implemented by the Member States was high, ${ }^{63}$ the negative consequences of persistent non-compliance on the Community legal order obvious, and the potential of financial sanctions as an efficient instrument of enforcement clearly established.

The relevance of the White Paper's approach

In the silence of the White Paper, an argument may be put forward that the Commission's role should follow the blueprint established when investigating cases of pre-litigation non-compliance. This approach is supported by the fact that, under Article 228(2) ECT, the Commission is acting in its capacity of guardian of the treaties. This element of continuity pleads in favour of a consistent approach. Furthermore, the letter of Article 228(2) is very similar to the letter of Article 226 ECT. It seems therefore logical to suggest that the similarity of the two provisions should lead mutatis mutandis to a similar approach. As a result, the Commission would globally act primarily as negotiator of the Member States compliance according to the litigation avoidance and litigation management framework, incorporating the cooperation and selectivity principles. On the other hand, one could emphasise that the nature of the violations in post-litigation noncompliance cases and their implications for the Community legal order are so serious that the suitability of the White Paper's framework is in need of reconsideration, together with the Commission's approach.

The serious nature of post-litigation infringements and its implications

The seriousness of the infringement is relevant here, as it is the key feature distinguishing infringements falling within the scope of Article 226 and those falling within the scope of Article 228(2). 
It is argued that instances of post-litigation non-compliance always entail a serious infringement of Community law. The criterion of the seriousness of the violation originates in the well known principle of the liability of a Member State for breach of EC law. ${ }^{64}$ In order for liability to arise, a Member State must inter alia be found to have committed a sufficiently serious breach of Community law.

As far as infringements procedures in general are concerned, any infringement is potentially sanctionable. There is no requirement that a certain threshold must be met regarding the serious nature of the infringement. Hence the reference to the seriousness of the breach is not on the surface, a determining factor of the Commission's approach. However, when addressing the issue of the failure of a Member State to give effect to a ruling of the European Court of Justice, the seriousness issue can not be disregarded because it is constant feature that such an infringement will qualify as serious, both in terms of implications for the Community legal order, and according to the definition of a serious breach of Community law by the Court. In the ECJ's own words, such a breach occurs when a Member State has 'manifestly and gravely disregarded the limits on its discretion'. ${ }^{65}$ A Member State not conforming with a ruling of the Court under Article 228(2) always manifestly and gravely disregards the limits on its discretion. Manifestly, because although Member States do indeed retain some autonomy in the choice of means to be used in order to bring an infringement to an end, the aim of compliance is not in itself left to the Member State's discretion. As a result, failure to come into line with Community law necessarily exceeds the limits of the Member State's discretion. Gravely because the obligation to comply is expressly stated in the EC Treaty in Article 228(1), clearly implied in Article 10 and further confirmed by the obligation Member States have to accept the compulsory jurisdiction of the Court of Justice as well as the authority and biding character of its rulings.

The question must therefore be asked of whether such a violation, which meets the seriousness criterion, affects the suitability of the White Paper's enforcement framework, and by extension, the role of the Commission in situations of post-litigation non-compliance.

\section{Is the White Paper's approach suitable for post-litigation situations?}

According to the White Paper, the effectiveness of Community law constitutes an overarching objective. Improving the effectiveness of the enforcement of Community obligations by the Commission in turn contributes significantly to the overall objective. It will now be demonstrated that the White Paper's framework based on litigation avoidance and management is at best ill-suited to situations of post-litigation non-compliance, and at worst counter-productive in terms of effectiveness. The Commission's role will be re-examined accordingly.

\section{Litigation avoidance, a redundant objective}

Litigation avoidance is based on the twin concepts of upstream cooperation and selectivity. Though recourse to these concepts proves to be effective under Article 226, it is doubtful whether their effectiveness is carried through in the context of post-litigation non-compliance.

It has been established that upstream cooperation is aimed at preventing the occurrence of infringements in the first place. In post-litigation non-compliance, the Commission is faced with two infringements: the original breach of Community obligations, which has not been resolved satisfactorily despite an infringement action under Article 226, and a second infringement consisting of the non-compliance with the European Court's ruling. It goes without saying that preventing the first infringement is irrelevant. It has been investigated, and clearly established through a judicial decision. As far as the second, compound violation is concerned, prevention is of limited value. The parameters of the infringement are clearly defined in the Court's ruling, and the Member State's obligation is to comply with the ruling by taking all appropriate measures to bring the original breach to an end. Furthermore, compliance partnerships, a key feature of litigation avoidance, are decidedly at odds from a post-litigation perspective. They involve an equal relationship between Commission and Member States, based on the common interest of avoiding conflict situations. Again, by the time the Commission considers engaging the proceedings under Article 228(2), the conflict between the Member State and the Community is ongoing and aggravated by the non-implementation of the ECJ's ruling. The onus is actually on the Member State concerned to comply with respect to both infringements. 
Turning now to the concept of selectivity, its usefulness may also be thrown into doubt. Two arguments support this view. Firstly, the Commission itself has acknowledged the seriousness of such violations: they are expressly included in the list of prima facie high priority cases, as they undermine the smooth functioning of the Community legal system. ${ }^{66}$ Secondly, as stated earlier, post-litigation infringements qualify as serious under the test elaborated by the European Court of Justice in State liability cases. The leap from State liability to infringement actions is a small one: if a violation of Community law is sufficiently serious to trigger the liability of the offending Member State, surely it is serious enough to warrant an infringement action. Distinguishing low and high priority cases thus becomes redundant as post-litigation infringements are necessarily serious.

To conclude on this point, there is little evidence that cooperation and selectivity are operating as effective vectors of effectiveness from a post-litigation perspective. Consequently, there is little scope left for the Commission's role as negotiator of the Member States' compliance.

Effective litigation management: a relevant objective

In contrast with litigation avoidance, the objective of effective litigation management retains a strong value from a post-litigation perspective.

By way of preliminary comment, it must be noted that this assertion is based more on considerations of effectiveness relating to the Community's interest in securing compliance with rulings of the European Court of Justice than on the basic management of the actual volume of cases to be dealt with by the Commission. If cases of post-litigation non-compliance have a noxious and perhaps disproportionate effect on the functioning of the Community legal system, there is comparatively less of them in numerical terms. ${ }^{67}$ Litigation management is based on the twin concepts of downstream cooperation and selectivity, which both remain relevant.

Downstream cooperation operates once an Article 228(2) infringement action is initiated by the Commission. Its principal objective is to bring the Member State concerned into line with Community law as expeditiously as possible if necessary by calling upon a Member State's obligation of cooperation under Article 10 ECT. In the context of post-litigation non compliance, enforced cooperation appears even more relevant as the unlawful behaviour of the Member State is judicially established. In that respect, it seems that the introduction of an obligation of notification of the measures adopted by the Member State concerned to bring the infringement to an end on the model initially used for the implementation of directives, would constitute an useful instrument for the Commission's monitoring of the Member State's compliance. Finally, the Commission's position is considerably strengthened by the availability of financial penalties under Article 228(2), which has proven to be a powerful incentive for Member States to finally come into line with Community law. ${ }^{68}$

Turning once more to selectivity, the concept remains relevant but not as an orientation instrument designed to establish priorities to be followed in the treatment of infringement procedures. Indeed, instances of post-litigation non-compliance are less numerous, ${ }^{69}$ thus considerably reducing the need for management priorities. However, as established earlier, since such cases are necessarily serious in nature, they should automatically be treated as high priorities by the Commission on the very basis of the selection criteria. The application of the principle of selectivity does not bring about the distinction between high and low priority cases and the associated differential treatment, but on the contrary points towards a uniform approach based on litigation. The main vector of compliance resides with the deterrent effect generated by impending litigation and the attached financial sanctions. In other words, in the present context, the objective of effectiveness relies upon the pre-determined, systematic use of the procedure provided for in Article 228(2). This is not without implications when considering the Commission's negotiator's role. The specific features of post-litigation cases are conducive of a reduction of the scope for negotiations: the strong correlation between the prospect of systematic litigation and compliance shows that the effectiveness of Community law may be best served by using systematic litigation rather than negotiation. Would this suggestion result in a loss of bargaining power for the Commission? Perhaps. But one has to ask if situations of post-litigation non-compliance form a legally adequate background for negotiations, bargaining and various other deals. At the heart of the matter is a Member State which has infringed its freely contracted Community obligations not only once but twice, and for good measure has overlooked a judgment of the Court of Justice in the process. 


\section{Conclusion}

A brief summary of the above findings is called for. Starting with instances of pre-litigation noncompliance, it has been suggested that, through the juridification of the concepts of cooperation and selectivity, the White Paper on Governance has lead to the inception of a coherent litigation avoidance and litigation management framework for the Commission to exercise its function of guardian of the treaties in accordance with the overarching objective of effectiveness. As a consequence, the Commission's primary role of negotiator of the Member States compliance is not only confirmed, but substantially reinforced.

In situations of post-litigation non-compliance however, the suitability of the framework has been questioned. In particular, doubts were raised regarding the relevance of the objective of litigation avoidance and the ability of the principles of cooperation and selectivity to operate as vectors of effectiveness. In contrast, the validity of the objective of litigation management was acknowledged. However, after establishing the serious nature of post-litigation infringements and the strong correlation between the perspective of systematic litigation and Member States' compliance, the suggestion was put forward that securing compliance might be more effectively achieved simply through systematic litigation.

In conclusion, this analysis of the impact of the White Paper on Governance demonstrates that the Commission's main contribution to the aim of effective enforcement is confirmed as its role as a tireless negotiator of the Member States' compliance, but that, in the specific context of postlitigation non-compliance, significant benefits may be derived from the Commission's acting as an undeviating prosecutor on behalf of the Community. 


\section{Notes}

I am indebted to the journal's anonymous reviewer as well as to my colleagues at the School of Law for their comments on an earlier draft.

${ }^{1}$ Cappelletti et al. (1986) p.21.

${ }^{2}$ Previously Articles 169 and 171 ECT.

${ }^{3}$ European Governance is defined as the rules, processes and behaviour that affect the way in which powers are exercised at European level.

${ }^{4}$ European Commission (2001b) p.5.

${ }^{5}$ lbid. p. 10.

6 Joerges (2002) p.445; Scott \& Trubek (2002) p. 1; Eberlein \& Kerwer (2004) p.221.

7 Such as framework directives or coordination.

${ }^{8}$ Audretsch (1987) p.52; European Commission (2004), p.3.

${ }^{9}$ Formerly Article 155. See first indent.

${ }_{10}$ Case 167/73, Commission v. France [1974] E.C.R. 359, at point 15.

11 Article 226 states:

'If the Commission considers that a Member State has failed to fulfil an obligation under this Treaty, it shall deliver a reasoned opinion on the matter after giving the State concerned the opportunity to submit its observations.

If the State concerned does not comply with the opinion within the period laid down by the Commission, the latter may bring the matter before the Court of Justice.'

Article 228(1) provides that:

'If the Court of Justice finds that a Member State has failed to fulfil an obligation under this Treaty, the State shall be required to take the necessary measures to comply with the judgment of the Court of Justice.'

12 Commission Européenne (2001) p.94.

13 Ibid. p.94.

14 Van den Bosche (1996) p.335.

15 'If the Commission considers that the Member State concerned has not taken such measures it shall, after giving that State the opportunity to submit its observations, issue a reasoned opinion specifying the points on which the Member State concerned has not complied with the judgment of the Court of Justice.

If the Member State concerned fails to take the necessary measures to comply with the Court's judgment within the time-limit laid down by the Commission, the latter may bring the case before the Court of Justice. In so doing it shall specify the amount of the lump sum or penalty payment to be paid by the Member State concerned which it considers appropriate in the circumstances.

If the Court of Justice finds that the Member State concerned has not complied with its judgment it may impose a lump sum or penalty payment on it.'

16 With the exception of areas of EC law subjected to special enforcement provisions or procedures such as competition law or state aids.

17 The provision came in force on $1^{\text {st }}$ January 1993, with the Treaty on European Union. The first application of Article 228(2) occurred in 1997. The first imposition of a sanction upon a Member State occurred in 2000, in case 387/97 Commission v. Greece [2000] ECR I-5047.

${ }^{18}$ European Commission (1996 and 1997b) p.2.

19 The data provided in the Annual Reports on Monitoring the Application of Community Law shows that 10 cases were under investigation for the year 1999, 32 in 2000, 47 in 2001, 62 in 2002, and 69 in 2003 respectively.

20 In 2003, 1290 individual complaints were registered whereas the Commission initiated 253 cases on the basis of its own investigations. See European Commission (2004) p.4.

${ }^{21}$ Discretion is, in the present context, defined by the Court of Justice as 'a power to decide upon the most appropriate means of ensuring the application of Community law'. See Case 131/84, Commission v. Italy [1985] E.C.R. 3531.

${ }^{22}$ Evans (1979) p.446.

${ }^{23}$ See Case 131/84, Commission v. Italy [1985] E.C.R. 3531.

${ }^{24}$ Candela Castillo \& Mongin (1996) p.51. 
${ }^{25}$ See second indent of Article 169 'The Commission [..] may bring the matter before the Court of Justice' (emphasis added). A mandatory referral would be worded in a noticeably different way, such as 'the Commission shall bring the case before the Court of Justice.

${ }^{26}$ Case 7/71, Commission v. France [1971] E.C.R. 1003 and case 247/87, Star Fruit [1989] E.C.R. 291; see also Harden (2002) p.470; Tomkins (2003).

${ }^{27}$ Gil Ibañez (1999).

${ }^{28}$ For a socio-legal analysis of the Commission's enforcement role, see Rawlings (2000) p.4.

29 European Commission (2001b) p.26; Commission Européenne (2001); European

Commission (2002b) p.5.

${ }^{30}$ European Commission (2001c) p.1.

${ }^{31}$ Rawlings (2000) p.7.

${ }^{32}$ Commission Européenne, Travaux préparatoires du Livre Blanc sur la gouvernance européenne, Rapport sur l'application du droit communautaire par les Etats membres et sur le contrôle de celle-ci par la Commission contenant des recommandations en vue de les améliorer du point de vue de la gouvernance démocratique européenne, p.6.

${ }^{33}$ European Commission, Communication on Better Monitoring of the Application of Community Law (2002) p.5.

${ }^{34}$ European Commission (2004) p.5.

${ }^{35}$ European Commission (2001 b) p. 25.

${ }^{36}$ Article 10 ECT provides that 'Member States shall take all appropriate measures, whether general or particular, to ensure fulfilment of the obligations arising out of this Treaty or resulting from action taken by the institutions of the Community. They shall facilitate the achievement of the Community's tasks. They shall abstain from any measures, which could jeopardise the attainment of the objectives of this Treaty.'

${ }^{37}$ European Commission (2002b) p. 14.

${ }^{38}$ See for example case C-52/84 Commission v. Belgium, [1986] ECR 89 at point 16 and case C-94/87, Commission v. Germany, [1989] ECR 175.

39 The Commission started to make a more systematic use of Article 10 in 2001, activating it on twenty occasions when Member States had failed to cooperate on infringement proceedings (in 2000, only seven such procedures were initiated). See European Commission (2002b) p.6.; European Commission (2002b) p. 6.

40 For an example of flexible approach towards the level of cooperation expected from Member States, see the 19th Annual Report, which states that the Commission starts Article 10 proceedings only where the Member State in question has repeatedly failed to cooperate, and not in instances where delays in processing files result from national administrations taking an excessive time to reply within the framework of infringement proceedings, COM (2002) 324 final p.6.

${ }^{41}$ Indeed, it states that ultimately the impact of European Union rules depends on the willingness and capacity of Member States authorities to ensure that they are transposed and enforced effectively, fully and on time and reiterates the idea that monitoring closely the application of Community law is an essential task for the Commission if it is to make the Union a reality for businesses and citizens. See European Commission (2001b) p. 25.

${ }^{42}$ Rawlings (2000) p. 10.

${ }^{43}$ European Commission (1997a) p.9.

${ }^{44}$ Commission Européenne (2001) p.99.

${ }^{45} \mathrm{lbid}$. at p. 98.

${ }^{46}$ The criteria for priority cases have evolved quite substantially since the inception of the concept of selectivity. To charter that evolution, see European Commission (1997a) p.9;

European Commission (2001 b) p.26; European Commission (2002b) p.11. In any case, the priority criteria are to be subjected to an annual review.

47 Breaches of the principles of the primacy and uniform application of Community law are examples of the former, the serious obstruction of the implementation of a common policy an example of the latter.

${ }^{48}$ European Commission (2002b) p. 11.

${ }^{49} \mathrm{lbid}$. at p. 15.

50 With the exception of the SOLVIT network, a much more recent creation. SOLVIT is an on-line problem solving network in which EU Member States work together to solve without 
legal proceedings problems caused by the misapplication of Internal Market law by public authorities. SOLVIT has been working since July 2002. The European Commission coordinates the network, which is operated by the Member States. The European Commission provides the database facilities and, when needed, helps to speed up the resolution of problems. The Commission also passes formal complaints it receives on to SOLVIT if there is a good chance that the problem can be solved without legal action. See http://europa.eu.int/solvit/site/ index_en.htm

${ }^{51}$ European Commission (2001 b) p.26.

52 European Commission (2004) p.4.

$53 \mathrm{lbid}$. at p. 7. These figures compare favourably with the statistics for previous years. In 2000 , the transposal rate was $96.59 \%$, in $200197.41 \%$ and in $2002,98.87 \%$. The progress in the transposal rate is particularly remarkable when taking into account the significant increase in the number of directives currently in force. At the end of 1982, 640 directives were in force, with an average transposal rate of $89.58 \%$. Twenty years later, 2240 directives were in force with an average transposal rate of $98.87 \%$, see European Commission (2003) p.7. ${ }^{54}$ European Commission (2004) p.7.

55 The demise of the Constitution for Europe has a particularly unfortunate impact regarding the enforcement of the obligation of notification. Article III-363, a new provision, conferred upon the Commission the discretion to apply for financial sanctions against a Member State where the infringement procedure was concerned with the failure to notify national implementation measures. Financial sanctions, in the form of a lump sum or a periodic penalty payment, were so far only available under the Article 228(2) procedure. The new provision allowed for sanctions to be applied for at a much earlier stage, when the Commission refers a case to the European Court of Justice under Article III-360 which was to replace Article 226 ECT. In giving Member States a strong incentive to come in line with Community law, such penalties have already proven their deterrent effect in the context of Article 228(2).

${ }^{56}$ European Commission (2002b) p. 12.

${ }^{57}$ Case C-304/02 Commission v. France, judgment of 12 July 2005, [2005] OJ C 217/3, available on http://curia.eu.int/jurisp/cgi-bin/form.plelang=eng

${ }^{58}$ Case 64/88 Commission v. France [1991] ECR I-2727.

${ }^{59}$ Case C-304/02 Commission v. France, judgment of 12 July 2005, [2005] OJ C217/3, available on http://curia.eu.int/jurisp/cgi-bin/form.plelang=eng

$60 \mathrm{lbid}$., paragraphs 98-113. The periodic penalty payment is imposed on a half-yearly basis, but is the equivalent of a 316,500 fine per day of delay in the compliance.

${ }^{61} \mathrm{lbid}$., paragraphs 81 and 114-116.

${ }^{62}$ So far, the Court of Justice had only imposed periodic penalty payments, and in only two instances. See case C-387/97 Commission v. Greece [2000] ECR, p. 1-5047 and Case C278/01 Commission v. Spain [2003] ECR, p. I-4141. The judgment of July 2005 is striking in that while the Commission had applied for the imposing of a periodic penalty payment only, the Court used its discretion to go beyond the Commission's application, and as argued by France beyond the letter of the Treaty, by imposing both a periodic and a lump sum payment. ${ }^{63}$ European Commission (2001 a) Annex V, p.1.

${ }^{64}$ See joined cases C-6 \& 9/90, Francovich v. Italy [1991] ECR I-5357.

${ }^{65}$ Case C-46/93, Brasserie du Pêcheur v. Germany [1996] ECR I-1029.

${ }^{66}$ As confirmed by their inclusion on the list of high priority cases, as they undermine the smooth functioning of the Community legal system. See European Commission (2002b) p. 11. ${ }^{67}$ Currently, 69 decisions of the Court of Justice handed down as of $31^{\text {st }}$ of December 2003 remained yet non-implemented by Member States. See European Commission (2004) Annex $\checkmark$ p.2.

68 In the vast majority of cases in which the Commission proposed to apply for such penalty payments to be imposed by the ECJ, the Member States concerned complied either before the case's referral to the Court or soon after.

${ }^{69}$ Compared to the number of cases dealt with under Article 226 ECT. 


\section{References}

Audretsch, H.A.H. (1987) Supervision in European Community Law: Observance by the Member States of their Treaty Obligations: a Treatise on International and Supra-national Supervision, Second Revised Edition, North-Holland, Amsterdam.

Candela Castillo, J. \& Mongin, B. (1996) 'Les infractions au droit communautaire commises par les Etats membres: Quelques apports clés de la jurisprudence récente de la Cour de Justice en matière de manquement', Revue du Marché Commun et de l'Union Européenne, $396,51$.

Cappelletti, M., Seccombe, M. and Weiler, J.H.H. (Eds) (1986) Integration Through Law, Methods, Vol 1 Tools and Institutions, Vol 2 Political Organs, Integration Techniques and Judicial Process, Walter de Gruyter, Berlin and New York.

Commission Européenne (2001), Travaux préparatoires du Livre Blanc sur la gouvernance européenne, Rapport sur l'application du droit communautaire par les Etats membres et sur le contrôle de celle-ci par la Commission contenant des recommandations en vue de les améliorer du point de vue de la gouvernance démocratique européenne, available on http:// europa.eu.int/comm/governance/governance eu/comm law en.htm

Eberlein, B. \& Kerwer, D. (2004) 'New Governance in the European Union: A Theoretical Perspective', Journal of Common Market Studies, 42, 221.

European Commission (1996) Memorandum on applying Article 171 of the EC Treaty, OJ C 242/6.

European Commission (1997a) 14th Annual Report on Monitoring the Application of Community Law, COM 299 final.

European Commission (1997b) Communication on the Method for Calculating Penalties, OJ C $63 / 2$

European Commission, (2001a) 18th Annual Report on Monitoring the Application of Community Law, COM 309 final, Annex V.

European Commission (2001b) White Paper on European Governance, COM 428 final. European Commission (2001c) White Paper on European Governance, Preparatory work, Recommendations for the Improvement of the Application of Community Law by the Member States and its Enforcement by the Commission, Staff Working Paper, available on: europa. eu.int/comm./governance/governance_eu/comm._law_en.htm.

European Commission (2002a) 19th Annual Report on Monitoring the Application of Community Law, COM 324 final.

European Commission (2002b) Communication on Better Monitoring of the Application of Community Law, COM 725 final.

European Commission (2003) 20th Annual Report on Monitoring the Application of Community Law, COM 669 final.

European Commission (2004) 21 st Annual Report on Monitoring the Application of Community Law, COM 839 final.

Evans, A. (1979) 'The Enforcement Procedure of Article 169 EEC: Commission Discretion', European Law Review, 4, 442.

Gil Ibañez, A. (1999) The Administrative Supervision and Enforcement of EC Law, Powers, Procedures and Limits, Hart Publishing, Oxford.

Harden, I. (2002) 'A quel avenir la mise en application centralisée du droit communautaire peut-elle s'attendre?', Revue du Droit de l'Union Européenne, 3, 461.

Joerges, C. (2002) Guest Editorial: 'The Commission's White paper on Governance in the EU - A Symptom of Crisis ?', Common Market Law Review, 39, 441.

Rawlings, R. (2000) 'Engaged Elites: Citizen Action and Institutional Attitudes in Commission Enforcement', European Law Journal, 6, 4.

Scott, J. \& Trubek, D. M. (2002) 'Mind the Gap: Law and New Approaches to Governance in the European Union' European Law Journal, 8, 1.

Tomkins, A. (2003) 'Of Institutions and Individuals: the Enforcement of EC Law' in Craig P. and Rawlings, R. (eds) Law and Administration in Europe, Essays in Honour of Carol Harlow, Oxford Universtiy Press, Oxford.

Van den Bosche, P. (1996) 'In Search of Remedies for Non-Compliance: The Experience of the European Community', Maastricht Journal of European and Comparative Law, 3, 375. 